811.163.41'367.625

$811.163 .41 ' 366$

https://doi.org/10.18485/sj.2018.23.1.15

МИЛАН В. СТАКИТ

Универзитет у Београду

Филолошки факултет
Оригинални научни рад

Примљен: 04. 01. 2018.

Прихваћен: 29. 01. 2018.

\title{
МОРФОЛОШКИ ДУБЛЕТИ ГЛАГОЛСКИХ ОБЛИКА ОД ИНФИНИТИВНЕ ОСНОВЕ ${ }^{* *}$
}

\begin{abstract}
У раду ће бити речи о дублетним глаголским облицима од инфинитивне основе, а то значи - о дублетним облицима инфинитива, аориста, имперфекта, глаголског придева радног, глаголског придева трпног и глаголског прилога прошлог. На основу обимне грађе из савременог српског језика покушаћемо да објаснимо како и зашто настају ови морфолошки дублети, чему сложе и како се даље развијају и дистрибуирају у савременом језику.
\end{abstract}

Кључне речи: глаголски облици, дублети, инфинитивна основа, инфинитив, аорист, имперфекат, глаголски придеви, глаголски прилог прошли, консонантске алтернације, аналогија

Под морфолошким дублетима подразумевамо различите форме одређеног глаголског облика, у овом случају од инфинитивне основе, од истог глагола, различите облике, на пример, инфинитива (дигнути и дићи), аориста (отргнух и отргох од отргнути), имперфекта (тецијах и течах од тећu), радног глаголског придева (затегнуо и затегао од затегнути), трпног глаголског придева (откривен и открит од открити), глаголског прилога прошлог (затегнувии и затегавии од затегнути).

"mstakic@open.telekom.rs

** Овај рад чини природну целину са већ објављеним радом под насловом Дублетни глаголски облици од презентске основе (Научни састанак слависта у Вукове дане 44/3, Београд 2015, стр. 7-22). 
Анализом прикупљеног материјала требало би показати и објаснити када, како и зашто настају морфолошки дублети и која им је улога у савременом српском језику. Примери дублетних облика прикупљени су из шестотомног Речника српскохрватскога књижевног језика Матице српске и Правописног речника у Правопису српскохрватскога књижевног језика Матице српске 1960. г. А одлучили смо се за ове изворе зато што су им примери акцентовани и поуздани, а осим тога ваља истаћи да је поменути Речник једини комплетан, довршен речник књижевног језика, док Правописни речник из 1960. г. не само што има акцентоване речи, за разлику од Речника у Правопису српскога језика из 2010. године, него је и знатно обимнији од овога .

О обличким глаголским дублетима уопште као ни о овима од инфинитивне основе, који су предмет овога рада, није много и није посебно писано. Помињани су у појединим граматикама мање-више узгред и као констатација да поред описаних облика поједини глаголи могу имати и друге, дублетне облике. Ово би био покушај да се прикаже систем свих глаголских морфолошких дублета, те да се они објасне - како настају, зашто се јављају и која им је улога у језику данас.

\section{ИНФИНИТИВ}

Од свих глаголских облика начињених од инфинитивне основе инфинитив има највише дублетних облика. Зашто је то тако, показаће анализа прикупљене грађе, али се унапред може констатовати да су сви остали облици (аорист, имперфекат, глаголски придеви и глаголски прилог прошли), као и њихови дублети, продукт морфолошког уобличавања, док је инфинитив резултат, пре свега, творбеног процеса. А најчешћи дублетни облици инфинитива су код глагола са инфинитивном основом на -ну-, а презентском на -не- (трећа Стевановићева врста).

Глаголи са инфинитивом на -ну-ти најчешће имају и паралелни облик са завршетком - $и$. Ти облици су или равноправни или се предност даје једном, а други се упућује на њега. Тако ћемо их и класификовати - у три групе, а унутар свеке водићемо рачуна о њиховој творбеној структури и разликоваћемо: глаголе који су са савременог језичког осећања прости, неизведени као и префиксалне глаголе чији се прости мотивни облици данас употребљавају и префиксалне глаголе који немају својих мотивних облика у живој употреби.

1. -

a) прости, непрефиксални глаголи:

вйкнути // вйћи (знак // користимо за обележавање дублетних облика), вр̈гнути // вйћи, дйгнути // дйћи, ма̀кнути // мӑћи сврш., нйкнути // нйћи, нйкне̄м, сврш., пйкнути 
// пӱћи пӱкне̄м сврш., стйгнути // стйћи, стйгне̄м сврш., та̀кнути // màћu, тӓкне̄м сврш.,

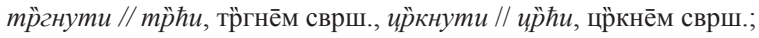

\section{б) префиксални глаголи са мотивним глаголима у живој употреби:}

до̀вргнути // до̀врћи сврш., дома̀кнути // дома̀ћи и до̀маћи сврш., досе́гнути, до̀се̄гне̄м // досе́ћи и до̀се̄ћu, до̀се̄гне̄м сврш (: се́гнути), до̀стигнути // до̀стићи сврш., дота̀кнути // дота̀ћи и доттаћи сврш., за̀вргнути // за̀врћи, за̀дигнути // за̀дићи, за̀легнути и залѐгнути // за̀лећи и залѐћи, зама̀кнути // зама̀ћи и за̀маћи, за̀мркнути // за̀мрћи, запо̀вргнути // запо̀врћи, зата̀кнути // зата̀ћи и за̀таћи, за̀такне̄м сврш., ѝзвргнути // ѝзврћи, иेздигнути // иेздићи, изма̀кнути // изма̀ћи и иेзмаћи, иेзникнути // ѝзнићи, испрѐвргнути, -гне̄м сврш. // испрѐврћи, -ргне̄м, ѝспукнути, -не̄м сврш. // ѝсnући, -укне̄м, иста̀кнути // иста̀ћи и ѝстаћи, на̀викнути // на̀вићи, на̀викне̄м сврш., на̀вргнути // на̀врћи, на̀вргне̄м сврш., на̀дигнути // на̀дићи сврш., налѐгнути и на̀легнути (се), на̀легне̄м (се) сврш. // налѐћи и на̀лећи, на̀леже̄м и на̀легне̄м сврш., нама̀кнути // нама̀ћи и на̀маћи, на̀макне̄м сврш., на̀nукнути // на̀nући, -укне̄м сврш., ната̀кнути // ната̀ћи и на̀таћи, на̀такне̄м сврш., оббикнути (се) // оेбићи (се), оेбикне̄м (се) сврш. [в : ø, оेдвикнути // оेдвићи, о̀двикнём сврш., оेдвргнути // оेдврћи, о̀двргне̄м сврш., оेдигнути // о̀дићи, о̀дигне̄м свр. [д : ø у префиксу од-, отуда његов аломорф о-], одма̀кнути // одма̀ћи и оेдмаћи, оेдмакне̄м сврш., оेдникнути // оेднићи, о̀дникне̄м сврш., ома̀кнути // ома̀ћи и о̀маћи, о̀макне̄м сврш., о̀мркнути // оेмрћи, оेмркне̄м сврш., опо̀вргнути // опо̀врћи, -вргне̄м сврш., по̀вргнути // по̀врћи, -вргне̄м сврш., по̀дигнути // по̀дићи, по̀дигнём сврш., подма̀кнути и подма̀ћи, по̀дмакне̄м сврш, подста̀кнути // подста̀ћи и по̀дстаћи, по̀дстакне̄м сврш., пойздигнути // пойздићи, -дигне̄м сврш., полёћи и по̀лећи по̀леже̄м и по̀легне̄м сврш. // полегнути -егне̄м, пома̀кнути // пома̀ћи и по̀маћи, по̀макне̄м сврш., по̀никнути // по̀нићи, -икне̄м сврш., поодма̀кнути // поодма̀ћи и поо̀дмаћи, попо̀дигнути // попо̀дићи, -дигне̄м сврш., попрйдигнути и попрйдићи, -дигне̄м сврш., поприма̀кнути, поприма̀ћи и попрѝмаћи, -ѝмакне̄м сврш., поста̀кнути // поста̀ћи и по̀стаћи, по̀стакне̄м сврш., по̀стигнути // по̀стићи, по̀стигнеем сврш., пота̀кнути // пота̀ћи и по̀таћu, по̀такне̄м сврш., поу̀здигнути и поу̀здићи, -игне̄м сврш., прѐбегнути // прёбећи, -егне̄м сврш., прѐдигнути // прѐдићи, -игне̄м сврш., према̀кнути // према̀ћи и прѐмаћи, прѐмакне̄м сврш., прѐпукнути // прѐnући, прѐпукне̄м сврш., прѐиркнути // прѐирћи, -цркне̄м сврш., прйвикнути (се) // прѝвићи (се),

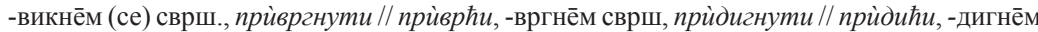
сврш., придо̀вргнути и придо̀врћи, -вргне̄м сврш., прима̀кнути // прима̀ћи и прѝмаћи, прѝмакнём сврш, прѝмркнути // прймрћи, -мркне̄м сврш., прйникнути // прѝнићи, -никне̄м, приेстигнути // прйстићи, -игнеем сврш., про̀вргнути // про̀врћи -вргне̄м (се), прома̀кнути // про̀маћи и прома̀ћи про̀макне̄м, сврш., про̀пукнути // про̀пући, -укне̄м сврш., прота̀кнути // прота̇ћи и про̀таћи, про̀такне̄м сврш., ра̀звргнути // ра̀зврћи, ра̀звргне̄м сврш., разма̀кнути // разма̀ћи и ра̀змаћи, ра̀змакне̄м сврш., ра̀спукнути // рàcnyћu, ра̀спукне̄м сврш., раста̀кнути // раста̀ћи и ра̀стаћи, ра̀стакне̄м сврш., слѐгнути // слѐћи, слёгне̄м и слёже̄м сврш., сма̀кнути // сма̀ћи, смӓкне̄м сврш., спота̀кнути // спота̀ћи и спо̀таћи, спо̀такне̄м сврш., ста̀кнути и ста̇ћи стӓкне̄м сврш., су̀стигнути // су̀стићи, -игне̄м сврш.,

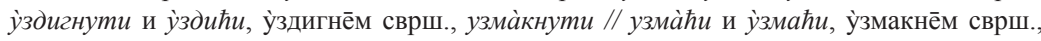
ума̀кнути // ума̀ћи и у̀маћи, у̀макне̄м сврш., уста̀кнути // уста̀ћи и у̀стаћи, у̀стакнём сврш., ута̀кнути // ута̀ћи и у̀таћи, у̀такне̄м сврш.;

в) префиксални глаголи без мотивних глагола у самосталној употреби:

до̀бегнути // доेбећи сврш, за̀бегнути // за̀бећи, забре́кнути // забре́ћи и за̀бре̄ћи, за̀бре̄кне̄м сврш., запре́гнути // запре́ћи и за̀прёћи, за̀пре̄гне̄м сврш, зате́гнути //зате́ћи и за̀те̄ћu, за̀те̄гне̄м сврш., ѝзбегнути // ѝзбећи, ѝзбегне̄м сврш., иेзљегнути, иेзљегне̄м (ијек) сврш. покр // иेзљећи, ѝзљегне̄м (ијек) сврш. покр.., испре́гнути // испре́ћи и ѝспре̄ћи, ѝспре̄гне̄м сврш., исте́гнути // исте́ћи и ѝсте̄ћи, ѝсте̄гне̄м свр, о̀дбегнути и оेдбећи, 
о̀дбегне̄м сврш. // о̀дбећи, о̀дбегне̄м сврш = одбегнути, осе́кнути (се) // осе́ћи и о̀се̄ћu (се), о̀се̄кне̄м (се) сврш., отпре́гнути // отпре́ћи и оттпре̄ћи, о̀тпре̄гне̄м сврш., поте́гнуmu, поте́ћu и по̀те̄ћu, по̀те̄гне̄м сврш. // поте́ћu и по̀те̄ћu, по̀те̄гнеем сврш. = потегнути, пренапре́гнути се // пренапре́ћи се и прена̀пре̄ћи се -а̀пре̄гне̄м се сврш., пренате́гнути // пренате́ћи и прена̀тёћи, -а̀те̄гне̄м сврш, препре́гнути // препре́ћи и прѐпрёћи, прѐпре̄гне̄м сврш., прѝбегнути и приेбећи, -егне̄м и приेбећи, -егне̄м = прибегнути, припре́гнути,

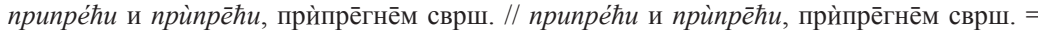
припрегнути, присе́zнути, присе́ћи и прѝсе̄ћu, прѝсе̄гее̄м сврш. // присе́ћu и прѝсе̄ћu, прйсегне̄м, прите́гнути // прите́ћu, прѝте̄ћи, прѝте̄гне̄м сврш., разбре́кнути се // ра̀збрёћи ce, ра̀збре̄кнём се сврш., распре́гнути, распре́ћи и ра̀спре̄ћи, ра̀спре̄гееем сврш // распре́ћu

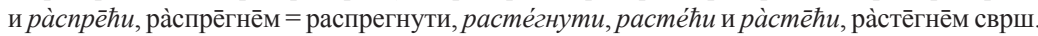
// расте́ћи и ра̀сте̄ћu, ра̀сте̄гне̄м сврш. растегнути, спре́гнути, спре́ћи и спре̄ћи // спре́ћи и спрёћu, спреิгне̄м сврш. = спрегнути, сте́гнути (и ређе сте́ћи и стёћu), стеิгне̄м сврш. и сте́ћи (се) и стёћи (се), стеิгне̄м (се) сврш. стегнути (се), сусте́гнути, сусте́ћи и су̀cmē $и$, су̀сте̄гне̄м // сусте́ћи (се) и су̀сте̄ћи (се), су̀стёгне̄м (се) сврш. = сустегнути (се), уेбегнути // уेбећи, у̀бегне̄м сврш., у̀збегнути // у̀збећи, -егне̄м сврш. упре́гнути, упре́ћи и у̀пре̄ћu, у̀пре̄гне̄м сврш. // упре́ћu и у̀пре̄ћu, у̀пре̄гнеем сврш.= упрегнути, успре́гнути, успре́ћu и у̀спре̄ћu, у̀спре̄гнём сврш. // успре́ћu и у̀сnре̄ћu, у̀спре̄гнём сврш. = успрегнути, усте́гнути, усте́ћи и у̀сте̄ћи, у̀сте̄гне̄м сврш. и усте́ћи (се) и у̀сте̄ћи (се), у̀сте̄гне̄м (се) сврш. = устегнути.

2. $-\underline{н y т u}$ и $-\underline{\hbar u}$ в. - $\underline{\text { нути: (облик на }-н y-m и ~ ј е ~ о с н о в н и, ~ а ~ о н а ј ~ н а ~}-\hbar и$ се упућује на њега):

а) клёкнути, -не̄м // клёћи, клёкне̄м сврш. песн. в. клекнути, мйкнути сврш. и несв // мёћи сврш. мркнути;

б) ѝстргнути, -не̄м сврш. // ѝстрћи, -ргне̄м сврш. в. истргнути, оेбвикнути (се), -не̄м (се) сврш. // оббвићи (се), -икне̄м (се) сврш. в. обвикнути (се), оттпукнути, -не̄м сврш. // оттпући, оेтпукне̄м сврш. отпукнути, оттргнути, -не̄м сврш. // о̀трћи, о̀тргне̄м 6. отргнути, по̀клекнути, -кне̄м сврш. // по̀клећи, -екнём сврш. в. поклекнути, по̀тргнути, -нём сврш. // по̀трћи, по̀тргне̄м в. потргнути, прѐвргнути, -нём сврш. // прѐврћи, -вргне̄м сврш. в. превргнути, ра̀стргнути, -не̄м сврш. // ра̀стрћи, ра̀стргне̄м сврш. в . растргнути, свйкнути (се), -не̄м (се) // свйћи (се), свйкне̄м (се) в. свикнути (се), смйкнути, -не̄м сврш. // смйћи се, смр̈кне̄м се сврш. в. смркнути се, у̀стргнути, -тргне̄м сврш. // у̀стрћи, -тргне̄м, сврш. в. устргнути;

в) набре́кнути, на̀бре̄кне̄м сврш. // набре́ћи и на̀бре̄ћи, на̀бре̄кне̄м в. набрекнути; напре́гнути, на̀прёгнеем сврш. // напре́ћи (се) и на̀пре̄ћи (се), на̀прёгнеем (се) в. напрегнути (се), нате́гнути, на̀те̄гнём сврш. // нате́ћи и на̀те̄ћи (се), на̀тёгнеем (се) сврш. в. натегнути (се), оте́гнути, о̀те̄гнеем сврш. // оте́ћи (се) и о̀те̄ћи (се), о̀те̄гнеем (се) сврш. в. отегнути (се), отпре́гнути // отпре́ћи и оттпре̄ћи, оेтпре̄гнём сврш. = отпрегнути; по̀дстрекнути, -не̄м и по̀дстрећи, -екнём в. подстректнути, посе́гнути, по̀се̄гне̄м сврш. // посе́ћи и по̀сёћи в. посегнути, пренѐбрегнути, -ѐбрегнём сврш. // пренѐбрећи, -ебрегне̄м сврш. в. пренебрегнути, пресе́гнути, прѐсе̄гне̄м сврш. // пресе́ћu, прѐсе̄гне̄м сврш. в. пресегнути, проेкликнути, -не̄м сврш. // проेклићи, -икнём сврш. в. прокликнути, проте́гнути, проेте̄гне̄м сврш. // проте́ћи (се) и про̀те̄ћи (се) проेте̄гне̄м (се) сврш. в. протегнути (се), прому́кнути, про̀мӯкне̄м и про̀мукнути, -не̄м сврш. // проми́ћи и про̀мӯћи, про̀мукне̄м сврш. в. промукнути; уте́гнути, у̀те̄гне̄м сврш. // уте́ћи (се) и у̀тёћи (се), уेте̄гне̄м (се) сврш. в. утегнути (се).

3. - -нути в. -ћи и -ћи (облици на -ну-ти упућују се на оне на - $ћ u)$ :

а) лёгнути, -нём сврш. в. лећи // лѐћи, лёже̄м и лёгне̄м, сврш., рѐкнути, рёкне̄м сврш. в. рећи // рѐћи, рёче̄м и рёкне̄м, 
б) оббрекнути, -не̄м сврш. в. обрећи // обрѐћи и оेбрећи, о̀брече̄м, обрѐче̄м и о̀брекнём сврш., по̀длегнути, -нём в. подлећи, // подлёћи и по̀длећи, по̀длеже̄м и по̀длегне̄м сврш., порѐкнути, по̀рекне̄м в. порећи // порѐћи и по̀рећи, по̀рече̄м и по̀рекне̄м сврш.,

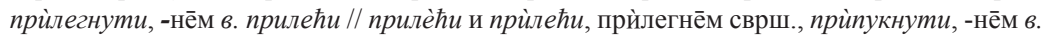
припући // прѝпући, -укне̄м сврш., уेрекнути и урѐкнути, у̀рекне̄м сврш. в. урећи // урѐћи, -ѐче̄м и у̀рећи, у̀рече̄м и у̀рекне̄м сврш.,

в) онемо̀нути сврш. в. онемоћи // онемо̀ћи и онѐмоћи, онѐмогнём сврш., по̀стригнути, -нём сврш. в. пострићи // по̀стрићи, -и́же̄м сврш..

Сви глаголи који имају дублетне облике инфинитива на -ну-ти и на -ћu свршеног су вида (притом увек треба имати у виду да су -ну- и -ти морфеме - прва је наставак за инфинитивну основу, а друга наставак за инфинитив - a да је -ћи гласовни завршетак, баз значења и без функцује). И сам постанак и опстанак таквих дублета у језику везан је за свршени вид тих глагола.

Српски језик је наследио из прасловенског глаголе на -ну-ти и свршеног и несвршеног вида (упор. ма̀кнути, дйгнути, стйгнути, пӱкнути, ... и чёзнути, вѐнути, тр́нути, то̀нути и сл.). Такође још у прасловенском језику -не-у презентској основи почело се везивати за свршени вид и у корелацији са -ну-, наставком инфинитивне основе, постали су творбено средство за перфектизирање имперфективних глагола. Као једини суфикс за грађење перфективних глагола од имперфективних суфикс -ну- /-не- добија велику продуктивност, а презентске основе на -не- чврсто се везују за свршени вид, постају, своје врсте, његово обележје. Поред тога, и захваљујући томе, облици презента са основом на -не- почињу се употребљавати код свршених глагола на - $и$, напоредо са старим примарним облицима презента: легнем поред лежем, рекнем поред речем и сл. Према овим секундарним облицима презента начињени су и нови, секундарни облици инфинитива: рекнути поред рећи, легнути поред лећи, вргнути поред вр̈ћи и сл. И то није све. Захваљујући томе што се презент са основом на -не- везао и за инфинитиве на -нути и за свршене глаголе на - $и$, код старих, примарних глагола на -ну-ти јавили су се, аналогијом и посредством презента са основом -не-, паралелни облици инфинитива са завршетком - $и$ : та̀ћи поред та̀кнути, ма̀ћи поред ма̀кнути, вйћи поред вйкнути, дйћи поред дйгнути, нйћи поред нйкнути, пӱћи поред пйкнути и др.

Све ово што смо видели код простих примарних глагола код префиксалних се напросто подразумева и унапред очекује. Конкретно: где је вйкнути // вйћи, ту је и на̀викнути // на̀вићи, оेбикнути (се) // оेбићи (се), оेдвикнути // оेдвићи, или поред дйгнути // дйћи биће и за̀дигнути // за̀дићи, ѝздигнути // ѝздићи, по̀дигнути // по̀дићи, уз ма̀кнути // ма̀ћи биће и зама̀кнути // зама̀ћи и за̀маћи, изма̀кнути // изма̀ћи и ѝзмаћи, ната̀кнути // ната̀ћи и на̀таћи, пома̀кнути // пома̀ћи и по̀маћи и сл. Чак и тамо где дублетни облици код простих, непрефиксалних глагола немају равноправну употребу, где се један облик инфинитива упућује на други, код префиксалних глагола подједнако су уобичајени, нпр. лёгнути, -неем в. лећи // лѐћи, лёжём и лёгне̄м, сврш (облик 
легнути упућује се на лећи, који пак чува оба облика презента лежем и легнем), али код префиксалних глагола нема тог упућивања, што значи да су оба облика подједнако у употреби, упор. налѐгнути и на̀легнути (се), на̀легне̄м (се) сврш. // налѐћи и на̀лећи, на̀леже̄м и на̀легне̄м, полѐћи и по̀лећи по̀леже̄м и по̀легне̄м сврш. // по̀легнути -егне̄м и сл.

Има и један, не мали, број префиксалних глагола чији се мотивни прости глаголи данас не употребљавају. И они имају инфинитивне дублете у савременом језику: йзбегнути // иेзбећи, ѝзбегне̄м сврш, забре́кнути // забре́ћи и за̀бре̄ћи, за̀бре̄кне̄м сврш., исте́гнути // исте́ћи и ѝсте̄ћи, ѝсте̄гне̄м свр, испре́гнути // испре́ћи и иेспре̄ћи, ѝспре̄гне̄м сврш., осе́кнути (се) // осе́ћи и òcēћu (ce), о̀се̄кне̄м (се) сврш. и др. Међу њима има и оних који се упућују на паралелне, дублетне облике: набре́кнути. на̀бре̄кне̄м сврш. // набре́ћи и на̀бре̄ћи, на̀бре̄кне̄м в. набрекнути, напре́гнути, на̀прёгнеем сврш. // напре́ћи (се) и на̀прёћи (се), на̀преегнеем (се) в. напрегнути (се), оте́гнути, оттёгнеем сврш. // оте́ћи (се) и отте̄ћи (се), оттёгнеем (се) сврш. в. отегнути (се), посе́гнути, по̀се̄гне̄м сврш. // посе́ћи и по̀се̄ћи в. посегнути, пренѐбрегнути, -ѐбрегнеем сврш. // пренёбрећи, -ебрегне̄м сврш. в. пренебрегнути, прому́кнути, про̀мӯкне̄м и про̀мукнути, -нём сврш. // прому́ћи и про̀мӯћu, про̀мукнём сврш. 8. промукнути; по̀стригнути, -нём сврш. в. пострићи // по̀стрићи, -и́же̄м сврш. Овај последњи пример разликује се од осталих утолико што му је мотивни глагол несвршеног вида (стрйћи, стри́же̄м), те је помоћу префикса начињен перфектизирани глагол (по̀стрићи, постри́жем), а напоредо са њим и у истом значењу почео се употребљавати аналогни перфектизирани глагол са типичним обележјима - основама -ну- /-не- (по̀стригнути, по̀стригнеем).

Осим глагола на - $и$, и примарни прости свршени глаголи са завршетком -сти временом су добили паралелне облике инфинитива са односом основа̄ -ну-/-не- као главним обележјем суфиксалног перфектизирања. Исти дублетни облици присутни су и код њихових префиксалних глагола:

сёднути, -не̄м, ијек. сјёднути, сврш. в. сести // сёсти, сёдне̄м и сёде̄м, ијек. сјёсти, сврш.; по̀седнути, -нём, ијек. по̀сједнути, сврш. в. посести // по̀сести, по̀седне̄м и по̀седе̄м, ијек. по̀сјести; запо̀седнути, -не̄м // запо̀сести, -о̀седне̄м и -о̀седе̄м, ијек. запо̀сједнути // запо̀сјести сврш.; о̀пседнути, -не̄м // оेпсести, -едне̄м и -еде̄м, ијек о̀псједнути // оेпсјести сврш.;

срётнути (се), -не̄м (се) сврш. в. срести (се) // срёсти, срётне̄м и срёте̄м сврш.; су̀сретнути (се), -не̄м (се) сврш.в. сусрести (се) // су̀срести, -етне̄м и -ете̄м.

Сличност ових глагола са глаголима на -ћи је у инфинитивном завршртку. Услед историјских гласовних промена, ни једни ни други немају наставак за облик инфинитива (упор. * ${ }^{*} e k t i=r e k-t i>r e-k t i>r e-k ' t i>r e-i t i>r e-t^{\prime} i>r e c ́ i$;

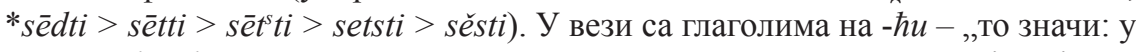
групама $k t$, cht, створеним деловањем закона отвореног слога, добијено је палатално $k$ ', $c h$ ', које се, нашавши се пред експлозивним сугласником, изгубило остављајући траг у несложном $i$, , тако је добијена група $i t$, која се развила на 
исти начин као етимолошко $t j$, тj. у $t$ '” (Бошковић 2000: 107). Глаголи на -сти имају још старији завршетак од оних на - $\hbar u$, јер је група $t t(<t t$ и $d t)$,измењена још у индоевропском прајезику; и дала је неједнаке рефлексе у појединим индоевропским језицима; у прасловенском - st: $t t>t s t>s t$ " (Бошковић 2000: 110). Јасно је, дакле, зашто завршеци - $и$ и -сти нису и не могу бити наставичи инфинитива са обележјима морфема, јер се у њима, у давној прошлости и по тадашњим фонетским законима, стопио део инфинитивног наставка са крајњим консонантом инфинитивне основе (која је била једнака корену), или се пак између експлозивног дентала на крају основе и истог таквог гласа $(t)$ у инфинитивном наставку развио фрикативни сугласник $s$, а потом је у групи tst елиминисан први експлозив (завршни сугласник основе). Јасно је и зашто у савременом језику код глагола овога типа не можемо инфинитивну основу одредити у облику инфинитива него од глаголског облика начињеног од инфинитивне основе додавањем обличких наставака, код нас је уобичајено да се од 1. лица једнине аориста одбије наставак -ох: сед-/ox/, cpem-/ox/, peк-/ox/ и сл. По нама, управо тај факат немогућности успостављања морфолошког модела инфинитивна основа + наставак = глаголски облик, поред несумњиве велике продуктивности основа -ну- /-не- у перфектизирању имперфективних глагола, условио је појаву овако великог броја дублетних облика код глагола на - $и$ и -сти, облика на -ну-ти, чији се инфинитив, непогрешиво и без проблема, образује по датом моделу: сед-ну- + -ти > седнути, срет-ну-ти > сретнути, рек-ну-ти > рекнути и сл.

Уз ове глаголе на -сти додаћемо још неке који такође имају дублетне облике инфинитива, али захтевају и посебна објашњења.

а) дёсти, дёде̄м, ијек. дјёсти сврш. = дёнути // дёти, дёде̄м, ијек. дјёти, сврш. = денути // дёнути, -нём, ијек. дјёнути, сврш. = дёсти и дёти („1. а. ставити, метнути, б. забаиити, затурити"); до̀дести и до̀дети, до̀дене̄м и доेдеде̄м, ијек до̀дјести и до̀дјети, сврш. [у РМС грешком: несврш.] „дотаћи, додирнути” // доेденути, -не̄м, ијек. до̀дјенути; за̀денути, -нём (ретко за̀деде̄м), ијек. за̀дјенути сврш. = задести и задети, за̀дести и за̀дети, -дене̄м и -деде̄м, ијек. за̀дјести и за̀дјети, сврш. = заденути; по̀денути, -не̄м, ијек. по̀дјенути, сврш = подести и подети // по̀дести, -еде̄м, ијек. по̀дјести, сврш. = поденути // по̀дети, -еде̄м, ијек. по̀дјети, сврш. = поденути; запо̀денути, -не̄м, ијек. запо̀дјенути, сврш. // запо̀де (c)mи, -ене̄м и -еде̄м, ијек. запо̀дје(с)ти сврш. заподенути; ѝзденути, -ене̄м и -еде̄м, ијек ѝздјенути, сврш. = ѝздести и издети // йздести и йздети, -ене̄м и -еде̄м, ијек ѝздјести и ѝздјети, сврш. = изденути; изодденути, -не̄м // изо̀де (c)mи, -еде̄м и-дије̄м, ијек. изо̀дјенути и изо̀дје(с)ти, сврш.; оेденути, о̀дене̄м, ијек оेдјенути сврш. // оेдести и о̀дети, о̀деде̄м и о̀дене̄м, ијек. о̀дјести и о̀дјети, сврш., оденути; прео̀денути, прео̀дести и прео̀дети, -о̀дене̄м, ијек. прео̀дјенути, прео̀дјести и прео̀дјети сврш.; са̀дести и са̀де$m u$, -деде̄м и -дене̄м, ијек. са̀дјести и са̀дјети, сврш. = саденути // са̀денути, -не̄м, ијек са̀дјенути, сврш. = садести и садети.

За дублетне облике типа дести // денути видели смо и како су настали и зашто, али код овог глагола и његових префиксалних облика јавља се и трећи облик инфинитива дёти, дёде̄м, ијек дјёти; по̀дети, -еде̄м и сл. Дакле, у употреби су три облика инфинитива истог глагола: дёсти, дёти и дёнути. 
Судећи по подацима које налазимо код Петра Скока, најстарији је облик дёти, ијек. дјёти. Своди се на индоевропски корен *dhè-, што значи да је е̌ у déti од индоевропског $\bar{e}$. Облик дести је постао редупликацијом основе - déd- на коју се додаје инфинитивни наставак: $d \check{d} d-+-t i>d \check{s} t i$. Оба облика - děti и děsti - имају презент dědēm (евентуални старији облик презента од děti није сачуван). Одавде надаље све је познато: глагол дети / дести је свршеног вида и аналошки у истом значењу почео се употребљавати и облик денути, денем, надаље су се уз све облике инфинитива почели употребљавати оба облика презента - дедем и денем, мада примећујемо и то да се уз инфинитив денути обично употребљава презент денем, који се готово равноправно са дедем користи и уз инфинитиве дети и дести.

б) пӓднути, -не̄м сврш. в. пасти // пӓнути, -не̄м сврш. в. пасти // пӓсти ${ }^{1}$, пӓдне̄м и пӓне̄м сврш.; до̀паднути и до̀панути, -не̄м сврш. в. допасти // до̀пасти, -адне̄м сврш.; оेтnаднути, -нём сврш. в. отпасти // о̀тпанути, -не̄м сврш. в. отпасти // о̀тпасти, адне̄м сврш.; прѐпаднути и прѐпасти, -адне̄м // прѐпанути, -не̄м в. препаднути, прѐпасти (ce) = препаднути (се); у̀паднути, -не̄м сврш. в. упасти // у̀панути, -не̄м сврш. в. упасти // у̀пасти, у̀падне̄м, сврш..

И глагол пасти има три облика инфинитива - поред пӓсти још и пӓднути и пӓнути са презентским облицима пӓднеем и пӓнемм (најстарији облик презента пӓдём готово и да није више у употреби). Облици паднути и панути су секундарни и почели су се употребљавати напоредо са пасти захваљујући свршеном виду и употреби презента са основом на -не- која је карактеристична за свршени вид (в. Маретић 1963: 241). А од ова два облика старији је панути и настао је гласовним путем - упрошћавањем сугласничке групе тешке за изговор, губљењем експлозивног сугласника $\partial$ испред сонанта $H$, а чим је био могућ изговор групе $\partial H$, враћен је глас $\partial$ у облик инфинитива.

в) стӓнути, стӓне̄м сврш. покр. в. стати // стӓти, стӓне̄м сврш.; на̀станути, не̄м сврш. в. на̀стати // на̀стати, -ане̄м сврш.; о̀станути, -не̄м сврш. остати // о̀стати,; изо̀станути, -не̄м сврш. в. изостати // изо̀стати, -остане̄м сврш.; уेстанути (се) нар. в. устати // уेстати, -ане̄м, сврш..

Глагол стӓти (и његове префиксалне изведенице) једини је са општим делом на вокал који, будући да је свршеног вида, има презент са основом на -не-, само са основом на -не-, а према презенту начињен је и инфинитив стаинути (у РМС означен са покр.) (в. Стакић 2010: 153).

г) занѐсти и за̀нести, -ѐсе̄м, сврш. в. занети // за̀нетти, -ѐсе̄м, ијек. за̀нијети сврш.; изнѐсти и ѝзнети в. изнети // ѝзнёти, -нѐсе̄м, ијек. иेзнијети; понѐсти в. понети // по̀не̄тu, -нѐсе̄м, ијек. по̀нијети, сврш.; пренѐсти, -ѐсе̄м сврш. в. пренети // прѐнёти, -нѐсе̄м и прѐнесе̄м, ијек. прѐнијети; придонѐсти, придо̀нести и придо̀не̄ти, -нѐсе̄м, ијек. придо̀нијети; принѐсти и прѝне̄сти, -нѐсе̄м // прйне̄ти, -нѐсе̄м, ијек. прйнијети; пронѐсти, -нѐсе̄м сврш. в. пронети // про̀нетти и проне́ти, -нѐсе̄м, ијек. про̀нијети; снѐсти, снѐсе̄м сврш. в. снети // сне́ти и снёти, снѐсе̄м, ијек снијѐти и снйјети, сврш.; унѐсти и у̀нести, -ѐсе̄м сврш. в. унети // у̀не̄ти, унѐсе̄м, ијек. у̀нијети, сврш. 
Глагол нѐсти, нѐсе̄м несвршеног вида у РМС има ознаку „заст.” и у погледу значења упућује се на глагол носити. У префиксалним изведеницама, међутим, његова употреба не само да је обична и продуктивна него има и паралелни дублетни облик: изнѐсти и ѝзне̄ти, -нѐсе̄м и сл.

За М. Стевановића ово је неправилан глагол: „Од глагола до̀нетти, а с њим су у свему једнаки: за̀не̄ти, о̀днетти и сл., основа презента је донесе-, а аориска (инфинитивна) основа донес-. Према томе, прва неправилност код овог глагола је у окрњености основе самога облика инфинитива: доне-. Од ове окрњене основе поред инфинитива се раде само: радни придев: дӧнео (дӧнелла, дӧнёло, дӧнеели ...) и глаголски прилог прошли: доेневвши или до̀невв). А аорист и трпни придев и од окрњене и од целе основе: до̀не̄х и донѐсох, дӧнесе (једино у овом облику); дӧнёт и донѐсен" (Стевановић 1970: 344). - Шта ми мислимо о „неправилним” глаголима уопште и могу ли се неправилно градити глаголи и њихови облици - писали смо раније (Стакић 2011). Ово Стевановићево тумачење, међутим, заслужује посебан коментар. Нити је „прва неправилност овог глагола у окрњености основе” нити се „од ове окрњене основе поред инфинитива граде само радни придев и глаголски придев прошли”, јер нема „окрњене основе” па самим тим ни облика̄ који се од ње граде. Зашто би се крњила инфинитивна основа нес- у инфинитиву? Група $\mathrm{cm}$ није тешка за изговор и никад се није упрошћавала. Осим тога, у глаголу доेнетти инфинитивна основа (чак и кад бисмо је могли добити одбијањем наставка -ти) није доне- него доне--, па бисмо морали објаснити ову дужину на вокалу $\bar{e}$, а то би било немогуће ако основу донё- добијамо крњењем пуне инфинитивне основе донес-. Друкчије треба објашњавати глаголе типа до̀нетти, прѐнетти, ѝзнетти и сл., онако како их је објаснио Т. Маретић - уопштавањем основе из аориста (Маретић 1963: 243). Додаћемо, да буде јасније, и следеће. Глаголи са инфинитивном основом на сугласник имали су три облика аориста (сва три је сачувао старословенски језик): најстарији, тзв. асигматски аорист, чије су облике 2. и 3. лица једнине сачували до данас као једине у та два лица (у осталим лицима се не употребљава, изгубио се из употребе); сигматски стари аорист који се изгубио из употребе у свим лицима код глагола овога типа, осим глагола нести односно његових префиксалних изведеница, нпр. до̀нёх, до̀нёсмо, до̀не̄сте, доेнёше (2. и 3. лице је, рекли смо, од асигматског аориста). Овај сигматски стари аорист грађен је од свих глагола - са инфинитивном основом на сугласник и на самогласник. Код глагола̄ са инфинитивном основом на сугласник при грађењу овога аориста имамо следеће карактеристичне моменте: а) дуљење основинског самогласника (што је изазвало и квалитативне промене $-\bar{o}->-a-,-\bar{e}->-\check{e}-) ;$ б) додавање непосредно на основу аористног суфикса $-c-$ в) губљење основинског сугласника (крајњег сугласника основе) испред $-c$ - односно $-x / c / u-;$ г) облици 2 . и 3 . лица једнине узимани су од асигматског аориста (в. Николић 2002: 189). Конкретно: нпр., 2. л. множине овог аориста 
глагола donesti развио се овако: nes- > nēs- > něs- (основински вокал $e$ се дуљио и прешао у е̌ ,jат"), nes- (>něs-) $+s>n e ̌ s-s-t e$ (на инфинитивну основу додат аористни суфикс $s$ и лични наставак за 2. л. мн. -te); něs-s-te > něste (губљење крајњег сугласника основе - něs-s-te $>n \check{e}-s$-te $>n e ̌ s t e)$. Трећи облик аориста је сигматски нови, који се препознаје по карактеристичним групама -ox/oc/ou- и који су сачували у српском језику сви глаголи са инфинитивном основом на сугласник: донесох, донесосмо, донесосте, донесоме. Када се све ово сагледа, јасно је да је у облику инфинитива донести стара инфинитивна основа до-нес-, а да је у инфинитиву донети / донијети сачувана основа сигматског старог аориста доне- / доније-. Иначе, сигматски стари аорист код глагола са инфинитивном основом на сугласник изгубио се из употребе (истиснуо га је сигматски нови аорист), једино се, неким чудом, сачувао код префиксалних глагола од глагола нести (осим, наравно, 2. и 3. лица једнине који су још старији, остаци су асигматског аориста).

Сви остали дублетни облици инфинитива лако се објашњавају, своде се на фонолошке аломорфе корена (дѐрати, дёре̄м несврш. = драти // дрӓти, дёре̄м несврш. = дерати // дре́ти и дреิти, дёре̄м и дреิм, ијек дријѐти и дрйјети несврш.), префикса (иза̀гнати, -а̄м и -а̀жене̄м покр. -а̀ждене̄м сврш.= изгнати // ѝзгнати, -а̄м сврш. = изагнати) или основе $($ о̀хватати, -āм несврш.= дохваћати несври. и уч. према дохватити // до̀хваћати, -а̄м = дохватати; ду́хати, дуิше̄м и дуิха̄м несврш. = дувати // ду́вати, дуิва̄м несврш. = духати; кора̀ųа$m u$, -а̄м несврш. корачати // кора̀чати, -а̄м несврш.; ка̀нути, кӓне̄м = капнути сврш. према капати // кӓпнути и кӓпнути, кӓпне̄м сврш. = канути; пѐґати, пёње̄м несврш. = пе́ти // nému (ce) и пе̂тu (ce), пёње̄м (ce) несврш. = пењати (се); раскрита́вати (се), -кр̀шта̄ва̄м (се) и раскр́штати (се), ра̀скр̄шта̄м (се)

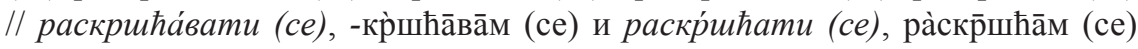
несврш. и уч. према раскрстити (се) и сл.).

\section{АОРИСТ}

Највише дублетних облика аориста имају глаголи III Стевановићеве врсте, са односом основа -ну- / -не-.

вйгнух, вр̈гну // вйгох, вйже (вр̈гнути), дйгнух, дйгну // дйгох, диже (дйгнути), за-

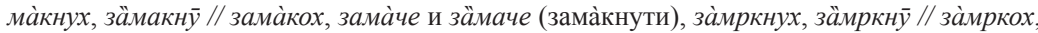
за̀мрче и зӓмрче (за̀мркнути, -не̄м), запре́гнух, зӓпрёгнӯ// запре́гох, зӓпрёже (запре́гнути, за̀пре̄гне̄м), измѐтнух, йзметну // изметтох, ѝзметох, измѐте, ѝзмете и ӥзмете (измѐтнути и йзметнути, ѝзметне̄м), иста̀кнух, йстакну // иста̀кох, иста̀че и йстаче (иста̀кнути, ѝстакне̄м), кйднух // кйдох (кйднути, -не̄м), ма̀кнух, мӓкну // ма̀кох, ма̀че и мӓче (ма̀кнути и ма̀ћи, мӓкне̄м), мйкнух, мйкну // мйкох, мёче (мр̈кнути, -не̄м), набре́кнух, набре́кну и

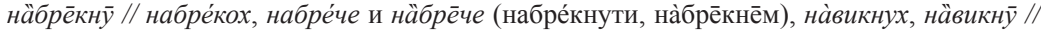
на̀викох, на̀виче и нӓвиче (на̀викнути и на̀вићи, на̀викне̄м), на̀zнух, нӓгну // на̀zох, на̀же и нӓже (на̀гнути, нӓгне̄м), на̀nукнух, нӓпукну // на̀nукох, на̀nуче и нӓпуче (на̀пукнути и 
на̀пући, -укне̄м), ната̀кнуx, нӓтакнӯ // ната̀кох, ната̀че и нӓтаче (ната̀кнути, ната̀ћи и на̀таћи, на̀такне̄м), нате́гнух, нате́zну, нӓте̄гнӯ // нате́zох, нате́же и нӓте̄же (нате́гнути, на̀те̄гне̄м), нйкнух, нйкну // нйкох, нйче (нйкнути и нйћи), оेдикнух, ӧдвикну // оेвикох, оेдиче и ӧдвиче (о̀двикнути и о̀двићи), опо̀вргнух // опо̀вргох (опо̀вргнути и опо̀врћи, -вргнём), оेтврднух // о̀тврдох, оттврдну, ӧтврдну и ӧтврде (о̀тврднути, -не̄м), оте́гнух, оте́гну и ӧтёгну // оте́гох, оте́же и ӧтёже (оте́гнути, оेтёгне̄м), оттргнух // о̀тргох, ӧтргнӯ и оेтрже, ӧтрже (о̀тргнути, -нём), по̀вргнух // по̀вргох, пӧвргнӯ и по̀врже, пӧврже (по̀вргнути и

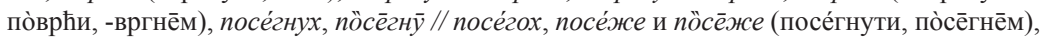

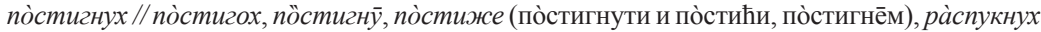
// ра̀спукох, .рӓспукнӯ, ра̀сnуче и рӓспуче (ра̀спукнути и ра̀спући, ра̀спукне̄м), расте́zнух // расте́гох, расте́гну и рӓсте̄гну, расте́же и рӓсте̄же (расте́гнути, расте́ћи и ра̀сте̄ћи, ра̀сте̄гне̄м), ра̀стргнух // ра̀стргох, рӓстргнӯ, ра̀стрже и рӓстрже (ра̀стргнути, -не̄м),

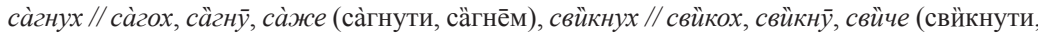

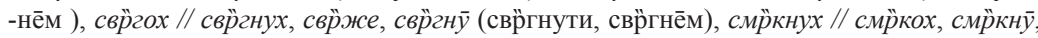

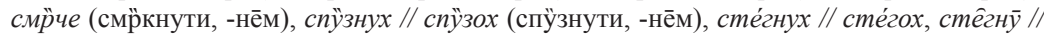

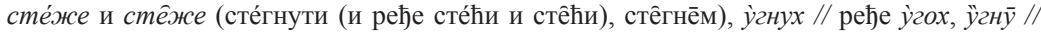

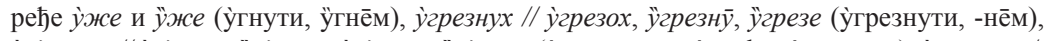

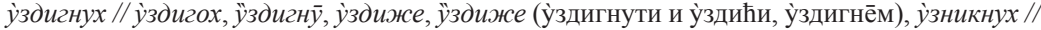

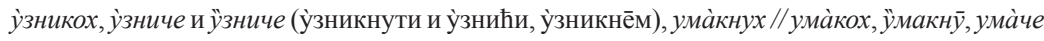
и ӱмаче (ума̀кнути, ума̀ћи и у̀маћи, у̀макне̄м), уста̀кнух // ycmàкох, ӱстакнy, yста̀че u

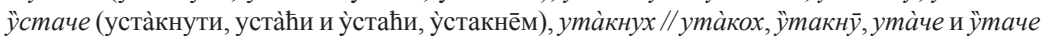
(ута̀кнути, ута̀ћи и у̀таћи, у̀такне̄м), штийкнух // штуйкох (штӱкнути, -не̄м).

Лако је уочити да су сви наведени глаголи (а има их још много) свршеног вида. Несвршени немају дублетних облика (упор. чёзнути - чёзнух, чёзну, кйснути - кйснух, кйсну, то̀нути - то̀нух, тӧну и сл.). Осим тога, сви ови глаголи имају корен на сугласник. Глаголи овога типа који испред основинског наставка -ну- имају вокал не знају за аористне дублете (упор. ми́нути -мúнух, ми́ну, ви́нути - ви́нух, ви́ну, пљйнути - пљйнух, пљӱну, увѐнути -увѐнух, ӱвену и сл.). Све ово би нас могло навести на погрешан траг и да олако „закључимо” да су и ови дублети као и они инфинитивни везани за глаголски вид и да, с тим у вези, према таћи имамо такох, таче, а према такнути - такнух, такну или према дигнути - дигнух, дигну а према дићи - дигох, диже. То би све тако било на први поглед, али бисмо се, ко зна по који пут, уверили да је оно што је „на први поглед” јасно и лако објашњиво, на други поглед, после дубље анализе, по правилу - погрешно. Конкретно, оваквом евентуалном тумачењу датих аористних дублета оштро се супротстављају ова два факта: прво, у старословенском језику немамо инфинитивних дублета (упор. tzknoti, navyknoti, dvigneti, omrbknQti и сл. или lešti, rešti и сл). Нема инфинитивних дублета, али „у старословенским споменицима налазе се већином двојаки облици аориста, тј. начињени од инфинитивне основе и корена", сачувани су углавном облици за 3. лице једнине (који су идентични са 2. лицем једнине):

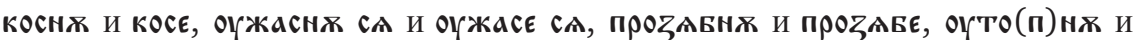

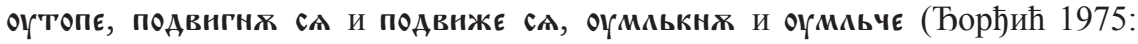
157). Други факат, не мање убедљив, је што има у српском језику глагола који немају дублетне облике инфинитива (немају облике са завршетком - $и$ ), 
а имају двојаке облике аориста: ѝзметнути, кӥднути, на̀гнути, ра̀стргнути, спӱзнути, уेгнути и др.

Од два облика типа такнух и такох (од такнути), по нашем мишљењу, старији је овај други. О томе нам сведочи и А. Меје: „В корневых глаголах с корнем, оканчивающимся на согласную, тип на -s очень рано начал замещаться типом на -охъ или на ехъ в зависимости от диалекта. Хотя в глаголических памятниках мы и встречаем аористы типа въсъ, н'大cъ и т. д., но их

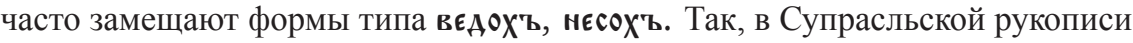

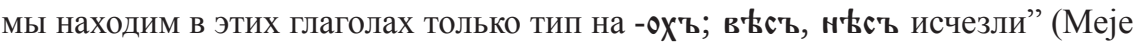
1951: 201). Ми полазимо од тога да су сви глаголи који имају инфинитивну основу на -ну- $(<-n Q-)$ а испред тога наставка сугласник били коренски глаголи, имали инфинитивну основу једнаку корену на сугласник. Поред А. Мејеа, то потврђује и Р. Бошковић кад говори о новом словенском сигматском аористу: „То је аорист који се гради само од основа на сугласник. То значи: од глагола I врсте - од оних глагола I врсте којима се основа инфинитива свршава на сугласник, и од глагола II врсте - од оних глагола II врсте којима се стара инфинитивна основа, она испред -nQ, од које се овај аорист и прави, свршава на сугласник" (Бошковић 2000: 194). Ти глаголи (коренски) су делимично сачувани и до данас у српском језику (пасти, сести, рећи, лећи и сл.). Имали су сва три аориста: најстарији, тзв. асигматски, од којег су се задржали у употреби облици 2. и 3. лица једнине до данас, сигматски стари који се у српском језику, осим код глагола нести (заправо, код његових префиксалних глагола: донети, изнети, пренети, унети и др), сасвим изгубио, потиснут је од тзв. сигматског новог аориста: падох, седох, рекох, легох и сл. Већи број тих коренских глагола преко основе -nQ- (>-нy-) прешли су у тематске основе, али су сачували аорист од старе, коренске, основе: вргнути - вргох, врже, дигнути - дигох, диже, макнути -макох, маче, навикнути - навикох, навиче и сл. Сасвим је нормално и разумљиво што су ови глаголи као тематски развили напоредо са старим сачуваним облицима и нове, које имају сви глаголи са основом на вокал: као видех, виде, видесмо, видесте, видеше тако и вргнух, вргну (вргнути), дигнух, дигну (дигнути), макнух, макну (макнути), навикнух, навикну (навикнути) и сл.

У овој групи глагола издвојићемо оне код којих се испред наставка -нугуби крајњи сугласник корена, сугласник који се јавља у аористу:

догр́нух // до̀гртох (догрнути), [т : ø], за̀кинух // за̀кидох (за̀кинути), [д : ø], за̀тиснух // за̀тискох (за̀тиснути), [к : ø], ѝзгинух // иेзгибох (ѝзгинути), [б : ø], на̀прснух // на̀прскох (на̀прснути), [к : ø], о̀ткинух // оेткидох (оेткинути), [д : ø], по̀zинух // по̀zибох

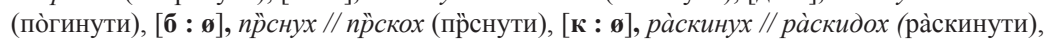
[д : ø], скӥнух // скйдох (скйнути), [д : ø], скре́нух // скрётох (скре́нути), [т : ø], уेкинух // уेкидох (уेкинути), [д : ø], и др. 
И ови глаголи, на свој начин, показују да су инфинитиви на -ну- млађи, те да је при њиховом образовању долазило до упрошћавања сугласничких група, тако што су се, по тадашњим гласовним законима, експлозивни сугласници губили испред $н$. Наш језик је сачувао оба аориста - старији коренски и новији основински. Овде морамо додати једну напомену: старији је, по времену настанка, сигматски стари аорист, којег су сачували глаголи са инфинитивном основом на вокал; имали су га и глаголи са основом (кореном) на сугласник, али је он код њих потиснут из употребе од сигматског новог аориста: старији су облици basъ, věsъ, rěhъ од bodohъ, vedoh, , rekohъ, али су се први готово сасвим изгубили из употребе, а други су сачувани до данас. Код глагола који су преко суфикса -nu- $(<-n Q-)$ из коренских прешли у основинске и сачували притом свој аорист од коренске основе (сигматски нови) развио се, аналошки према свим другим глаголима са основом на вокал, и нови аорист: поред сачуваних облика дигох, макох, такох глаголи диг-ну-ти, мак-ну-ти, так-ну-ти развили су и нове, аналошке аористне облике дигнух, макнух, такнух и сл.

Пажњу заслужује и један једини глагол који је поред сигматског новог сачувао и облике сигматског старог аориста - глагол nesti који се данас употребљава само са префиксима и у новом облику инфинитива, начињеном од основе старог сигматског аориста.

до̀нёx // донѐсох (доेнёти), ијек. до̀нијех // донѐсох (доेнијети, донѐсе̄м), по̀днёх // поднѐсох (по̀днёти, -нѐсе̄м), придо̀не̄х, прӥдонё // прйдонесох, прӥдонесе (придо̀не̄ти, придонѐсе̄м), снеิх, сне̂ // снѐсох, снёсе (сне́ти, снѐсе̄м), ијек. снйјех, снйје // снѐсох, снёсе (снијѐти и снйјети, снѐсе̄м), у̀знёх, ӱзнее // узнѐсох, ӱзнесе (у̀зне̄ти, -ѐсе̄м), изнѐсох, йзнесе // ѝзнёх, ређе ӥзнё (ѝзнёти, -нѐсе̄м), разнѐсох, рӓзнесе // ра̀знеех, ређе рӓзнё (ра̀знёти, -ѐсе̄м),

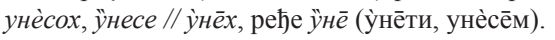

Прости глагол нести несвршеног вида више се не употребљава (у РМС има оснаку „заст.”), замењен је глаголом носити са истим значењем. Сачуван je, међутим, са префиксима у перфективизираним глаголима, али са новим обликом инфинитива - доेнёти, ѝзнёти, по̀не̄ти, у̀не̄ти и сл. Овај нови облик инфинитива настао је под утицајем сигматског старог аориста код којег је долазило до дуљења коренског вокала $e>\bar{e}>\check{e}$ (упор. ијек. до̀нијети, иेзнијети, по̀нијети, уेнијети и сл.). Из овога следи да су старији облици аориста типа до̀не̄x (ијек. доेнијех), сачувани облици сигматског старог аориста, и на основу њих начињен је и нови облик инфинитива доेнети место старијег (до)нести. За ово имамо макар три поуздана доказа: прво, презент донесем, изнесем, понесем и сл. у којем није било никаквог дуљења, друго, паралелни аорист донѐсох, изнѐсох, понѐсох и сл., облици сигматског новог аориста који су, као и они претходни, начињени од корена нес-, треће, поред облика 2. и 3. лица типа ӥзне̄, рӓзнё, ӱзнее и сл. стоји (у РМС) напомена „ређе”. Ово последње тражи и додатни коментар. Стари сигматски аорист је у 2. и 3. лицу једнине имао облике асигматског аориста (то нам несумњиво потврђује старословенски језик), те бисмо у облицима јединог сачуваног глагола нести и његових префиксалних 
облика у 2. и 3. лицу једнине очекивали само облике донесе, изнесе, разнесе, унесе и сл. Међутим, нови облици инфинитива типа донети имају основу на вокал, а сви такви глаголи имали су у ова два лица чисту инфинитивну основу, отуда је јасно зашто се поред обичних облика типа изнесе, разнесе и сл. јављају, спорадично и „ређе”, облици једнаки новој инфинитивној основи ӥзнее, рӓзнё.и сл.

На крају - неколико глагола са секундарним дублетним облицима аориста, који су главни „кривци” што не можемо прихватити јединствен начин добијања инфинитивне основе за све глаголе, не можемо прихватити правило да се „инфинитивна основа најбоље распознаје у првом лицу једн. аориста, и добија се одстрањивањем наставка -x (-оx)" (в. Симић 2001: 181), јер ти глаголи имају два различита облика аориста, али једну инфинитивну основу, која им се завршава на вокал и добија одузимањем инфинитивног наставка -ти. Такви глаголи су:

\begin{abstract}
знӓх // знӓдох (знӓти, знаิм и зна́де̄м), препо̀знах, препо̀зна и прёпозна̄, препо̀знасмо // препо̀знадох, препо̀знаде, препо̀знадосмо... (препо̀знати, препо̀зна̄м), мо́рах // мо̀радох (мо́рати, моิра̄м, несврш.), да̄x, даิ, дӓсмо... // дӓдоx, дӓде ..., (дӓти, да̂м), до̀даx, дӧда $u$ до̀да, до̀дасмо // до̀дадох, до̀даде, до̀дадосмо (до̀дати, до̀да̄м), ѝмах, ӥма̄ и иेма, иेмасмо... // ѝмадох, ѝмаде, ѝмадосмо... (ѝмати, ѝма̄м), стӓх // стӓдох (стӓти, стӓне̄м), у̀стах // устадох, 2 -3. л. у̀ста // у̀стаде (у̀стати, -ане̄м), хтёх, хтё // хтёдох, хтёде (хтёти, хо̀ћу, хӧћеш, през. у служби футура ІІ и у приповедању: хтёдне̄м), смёдох, смёде, смёдосмо...// смёх, смё, смёсмо (смёти , сме̂м).
\end{abstract}

Сви ови глаголи (а има их још, нпр. умети, умем - аор. умех, уме // умедох, умеде и др.) имају само један облик инфинитива (који се завршава на вокал), и једну инфинитивну основу: зна- (од знати), препозна- (препознати), мора(морати), да- (дати), дода- (додати), има- (имати), ста- (стати), уста- (устати), хте- (хтети), сме- (смети), уме- (умети) и др. Њихови дублетни облици аориста са завршетком -д-ох (знадох, препознадох, морадох, дадох, имадох, стадох, устадох, хтедох, смедох, умедох и др.) добијени су аналошки према презенту или према глаголима којима се инфинитивна основа завршава на -д- (красти - крад-ох, бости - бод-ох, одвести - одвед-ох и сл.), те би од њих, од наведених аналошких облика аориста, било погрешно одређивати инфинитивну основу.

\title{
ИМПЕРФЕКАТ
}

Код овога глаголског облика нема много дублетних облика. Знатно их је мање него код инфинитива и аориста. Разлог би био не само у томе што се ти дублети своде, мање-више, на двојаке наставке и не само у познатој чињеници да се овај облик гради само од имперфективних глагола него и међу њима, углавном, од оних чија се инфинитивна основа завршава на сугласник. И пре но што наведемо ексцерпиране примере - једна напомена. За разлику од 
увреженог мишљења међу граматичарима да се овај глаголски облик гради од обеју основа, ми сматрамо, а то смо и документовано образлагали, да се он (будући да је претеритални облик) гради само од инфинитивне основе (в. Стакић 2012: 23-61).

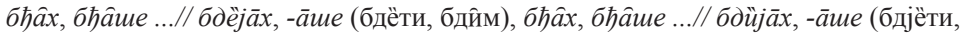

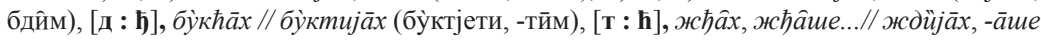

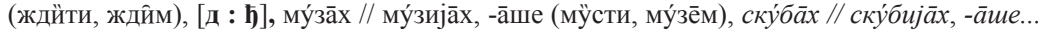
(ску́псти и скуิпсти, ску́бе̄м), браิх, браิще ...// бѐрија̄x , -а̄ще ... // бёра̄x, -а̄ще (брӓти, бёре̄м),

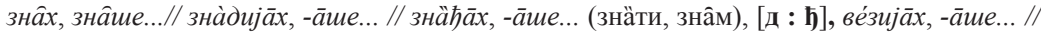
ве́за̄x, -а̄ще.. (ве́сти и веิсти, ве́зе̄м), вр́зија̄x ce, -а̄mе ce // вр́за̄х се, -а̄ще се (вр́сти се, вр́зе̄м

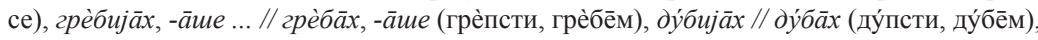
зе́бија̄ $x$, -а̄ще... // зе́ба̄x, -а̄ще... (зе́псти, зе́бе̄м), тре́сија̄x //mpécāx, -а̄me (тре́сти, тре́се̄м),

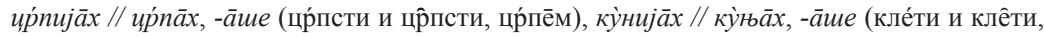

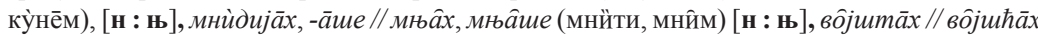

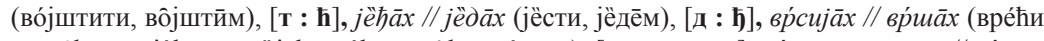

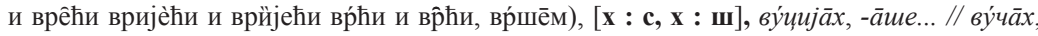

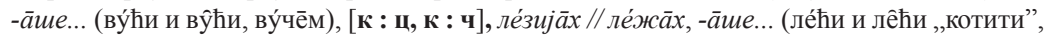

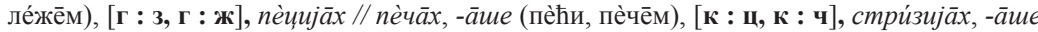

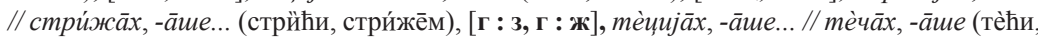

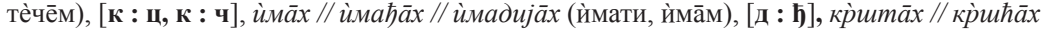
(кр̀стити, -йм), [ст : шт, ст :шћ], смѐдија̄ // смёја̄x (смёти (ек.), сме̂м).

Већи део дублетних облика имперфекта потичу од двеју врста наставака

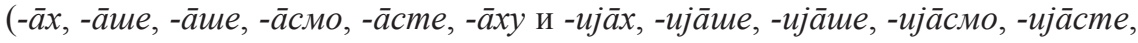
-ијāxy), који се додају на инфинитивну основу, када се она завршава на суглас-

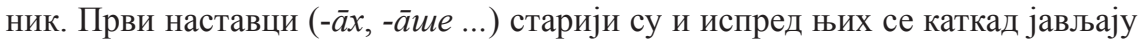
консонантске алтернације, различитог порекла. Други (-ијāx, -ија̄ще ...) су новији и испред њих алтернирају само задњонепчани сугласници. Управо те алтернације сугласника $\kappa, 2, x$, које се јављају код обеју врста наставака, недвосмислено показују који су наставци старији: пећu-nецฺијах и печах, meћu - тецијах и течах, стрићи - стризијах и стрижах, врћи, вршем - врсијах и

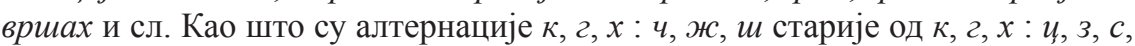
тако су и облици типа печах старији од оних типа пещијах. Још конкретније:

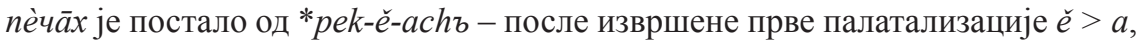
потом се то $a$ сажело са $a$ из наставка у једно дуго $a(a a>\bar{a})$; nѐuија̄ $x$ је постало (према Белићевом тумачењу) од *pek-ijah, додавањем на инфинитивну основу наставка -ија̄x који је настао перинтеграцијом из облика типа umé-achъ, код којих је -е̌- наставак инфинитивне основе, на коју су додавани наставци -ach -aše ... Та перинтеграција је извршена на српском терену, када прасловенске палатализације као гласовне промене нису деловале, а њихови резултати - гласовне алтернације распоређене су тако што је у облицима речи испред $e$ било $\kappa: ч, 2: ж, x: u$, а испред $u-\kappa: u, 2: 3, x: c$. Додуше, у екавском изговору очекивали бисмо - $j \bar{a} x$, а не -иjāx, али, по Белићевом тумачењу, овде имамо $u$ као код компаратива старији место старејu (од starěji) - под утицајем наших јужних и западних говора (Белић 1999: 374). 
Ти нови облици имперфекта на -иjāx, -ија̄ще учврстили су се, поред оних на $-\bar{a} x$, $-\bar{a} щ е$ код свих глагола чија је инфинитивна основа једнака корену и завршава се на сугласник: вести - везијах и везах, грепсти - гребијах и гребах, трести - тресијах и тресах, ирпсти - ирпијах и ирпах и сл., с тим што су код њих и ови други облици (на $-\bar{a} x,-\bar{a} ш е . .$.$) новијег порекла. Наиме, у старим$ облицима имперфекта, забележеним у старословенском језику, tręs-ё-achъ, tręs-ě-aše ... касније је, на српском терену, извршена прогресивна асимилација - tresěěchъ, што је касније контракцијом дало tresěh. Било је таквих облика у нашем језику између XV и XVIII века, а касније су их заменили новији

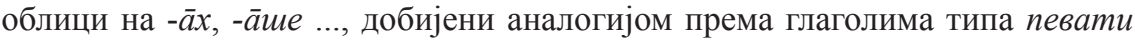
- певах, певаме и сл.

О осталим дублетним облицима имперфекта у савременом српском језику, који су везани углавном за различите облике инфинитивне основе, писали смо раније. Да бисмо избегли понављање, упућујемо на два раније објављена рада (в. Стакић 2012: 23-61 и Стакић 2013: 87-109).

\section{ТРПНИ ГЛАГОЛСКИ ПРИДЕВ}

Ово је други глаголски облик за који се мисли и тврди да се гради од обеју основа. Ми пак сматрамо, а то и доказујемо да се и он, као претеритални глаголски облик, гради само од инфинитивне основе (в. Стакић 2014: 147-166). И сви дублетни облици своде се, видећемо, на облике трпног глаголског придева који се граде од истог глагола (од његове инфинитивне основе) помоћу две врсте наставака.

-ен // -т: бйти1, бйје̄м, бѝјен, -ѐна, -ѐно // песн. биิт, - $a,-о$; збйти, збйје̄м, збйјен, -ѐна // збитт; ѝзбити, йзбије̄м, избйјен, -ѐна, -ѐно // ӥзбйт; вйти, вйјеем, вйјен, -ѐна // виิт, на̀вити, нӓвије̄м, навѝјен, -ѐна, -ѐно // нӓвйт, - $а$. -о; оба̀вити, о̀бавије̄м, обавйјен // ӧбавйт; о̀пити, ӧпије̄м, опѝјен, -ѐна, -ѐно // ӧпйт; подна̀пити се, по̀днапије̄м, поднапйјен, -ѐна, -ѐно // пӧднапитт; ра̀збити, рӓзбије̄м, разбйјен, -ѐна, -ѐно // рӓзбйт; ра̀звити, рӓзвије̄м, развйјен, -ѐна, -ѐно // рӓзвйт; са̀вити, сӓвије̄м, савѝјен, -ѐна, -ѐно // сӓвйт; свйти, свйје̄м, свйјен, -ѐна, -ѐно // свйт; у̀бити, ӱбијём, убйјен, -ѐна, -ѐно // ӱбитт; у̀вити, ӱвије̄м, увйјен, -ѐна, -ѐно // у̀вйт;

по̀вити, пӧвије̄м, пӧвйт // повйјен, -ѐна, -ѐно; зау̀збити, за̀узбије̄м, за̄узбйт //заузбйјен; пйти, пйје̄м, питт // пѝјен, -ѐна; преса̀вити, прѐсавије̄м , прёсавйт // пресавйјен, -ѐна;

дёсти, дёде̄м, дёm, - $a$ // дѐвен, -ѐна; за̀трти, зӓтре̄м и за̀таре̄м, зӓтртm // затр̀вен, -ена; ѝзути, йзује̄м, йзӯm // изу̀вен, изувѐна; крйти, крйје̄м, криิт // крѝвен, -ѐна, -ѐно; на̀дути,

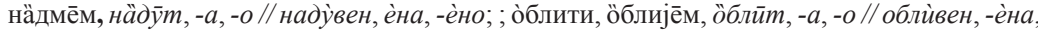

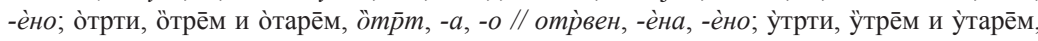

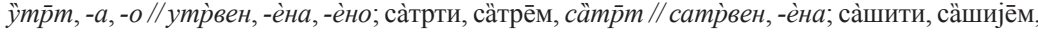
сӓшйт // сашйвен; тр̀ти, треิм, $m \hat{p} m$ // трेвен, -ѐна; у̀мити, ӱмије̄м, у̀мйm // умйвен; шйти, шйјём, шиิт // шйвен, -ѐна;

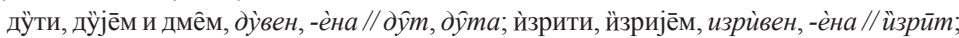
лйти, лйје̄м, лйвен, -ѐна, -ѐно // лит, - $a$, -о; мйти, мйје̄м, мйвен, -ѐна, -ѐно // мйm, - $a,-o$; о̀ткрити, ӧткрије̄м, открѝвен, -ѐна, -о // ӧткрйm; са̀крити, сӓкрије̄м, сакрйвен, -ѐна, -ѐно // сӓкрӣт; лйти, лйје̄м, лѝвен, -ѐна // лит, литта; 
за̀не̄ти, -ѐсе̄м, иј. за̀нијети, занѐсен, -ѐна // зӓне̄m; ѝзне̄ти, -нѐсе̄м, изнѐсен, -ѐна // йзнетm; о̀дне̄ти, -ѐсе̄м, ӧднёm, - $a,-о / /$ однѐсен, -ѐна, -ѐно; по̀дне̄ти, -нѐсе̄м, поднѐсен, -ѐна, -ѐно // пӧдне̄m; по̀не̄ти, -нѐсе̄м, понѐсен, -ѐна, -ѐно // пӧне̄m; прѐне̄ти, -нѐсе̄м и прѐнесе̄м, пренѐсен, -ѐна, -ѐно //прёнёm; ра̀зне̄ти, -ѐсе̄м, разнѐсен, -ѐна, -ѐно //рӓзнёm; у̀зне̄ти, -ѐсе̄м, узнѐсен, -ѐна, -ѐно // ӱзнетт; у̀не̄ти, унѐсе̄м, унѐсен, -ѐна, -ѐно // ӱнёm;

-н // -т: да̄ти, да̂м, да̂н, да̂на, -о и да́на, -o// дâm, да̂ma, -о и да́ma, -o; звӓти, зо̀ве̄м , зва̂н // зва̂m; знӓти, знаิм и зна́де̄м , знаิн // зна̂m; клӓти, кӧље̄м, кла̂н // кла̂m; прӓти, пёре̄м и пѐре̄м, праิн // пра̂m; слӓти, шӓље̄м, слаิн // cла̂m, - $a,-o$;

доेгнати, -а̄м и до̀жене̄м, дӧгна̄н // дӧгна̄m; зара̀внати, -а̄м, зӓравна̄н // зӓравна̄m;

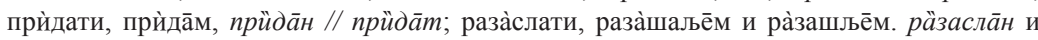

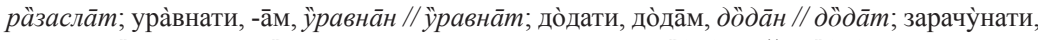
-чу̀на̄м, за̄рачуна̄н и зӓрачуна̄m; придо̀дати, -до̀да̄м, прйдода̄н // прйдода̄m; раза̀слати, раза̀шаље̄м, рӓзасла̄н // рӓзасла̄m;

-ен (ст : шћ // шт): извла́стити, ѝзвла̄стӣм, ѝзвла̄шћен // ѝзвла̄штен; ма́стити, маิстйм, маิшћен // маิштен; овла́стити, о̀вла̄стйм, о̀вла̄шћен // о̀вла̄штен; ома́стити, о̀ма̄стӣм, о̀ма̄uћен / о̀ма̄штен; опу́стити, о̀пӯстӣм, о̀пӯшћен // о̀пуштен; повла́стити, по̀вла̄стӣм, по̀вла̄шћен // по̀вла̄штен; пома́стити, по̀ма̄стӣм, по̀ма̄шћен // по̀ма̄штен; прела́стити, прѐла̄стӣм, прѐла̄шћен // прѐла̄штен; према́стити, прѐма̄стӣм, прѐма̄шћен // прѐма̄штен; расве́стити, ра̀све̄стӣм, ра̀све̄шћен // ра̀све̄штен; ума́стити, у̀ма̄стйм, у̀ма̄ићен // у̀ма̄штен.

Од глагола бити, бијем, вити, пити и њихових префиксалних облика трпни глаголски придев се гради од инфинитивне основе и двојаких настава-

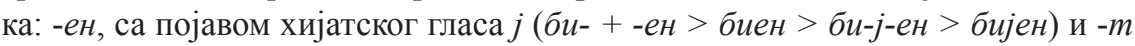
(би- $+-m>$ бит, вит, пит и сл.).

Глаголи дети, (за)трти, (из)ути, крити, (на)дути, (у)мити, шити, (из)рити, лити, мити и сл. такође овај облик граде од инфинитивне основе и истих двојаких наставака -ен и -m, само што се између коренске основе и

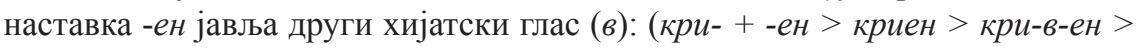
кривен, поред кри- + -m> крит и сл.).

О глаголу нести // нети, сачуваном у савременом језику само у префиксалним облицима, опширно смо писали напред, у вези са инфинитивом. Овде ћемо додати само то да су оба дублетна облика трпног глаголског придева начињени од инфинитивне основе - занесен, од старе инф. основе, једнаке корену (-нес-) и наставка -ен; а зӓнёт од новије инф. основе, добијене из старог сигматског аориста, и наставка - $m$ (зӓнетт, ӥзнеет, ӧднетm и сл.).

Дублетни облици као што су: даิн, - $a$, -о // да̂m, - $a,-o$ (дати), зван // зват (звати), пран // прат (прати), слан // слат (слати), уравнан // уравнат (уравнати) и др. поуздано сведоче о експанзији наставка - $m$, који, по А. Белићу, имају: глаголи на -ну-ти (дигнут), глаголи са инф. основом на $\bar{e}$ (нӓчетm), $\bar{p}$

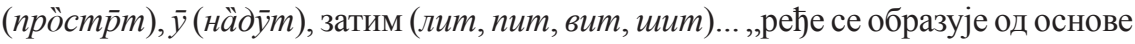
на $a$ : nöзна̄m, дâm, клаิm, сйjа̄m и сл.” (Белић 1999: 387). На то М. Стевановић додаје: „, Од осталих само неки, најчешће глаголи ( $\mathrm{V}$ вр.) који имају а и у основи инфинитива и у основи презента, у трпном придеву такође имају наставак -m: да̂m, прӧда̄m, ӱпозна̄m, ӱда̄ma" (Стевановић 1970: 339). Има, међутим, 
много више примера који потврђују ширење наставка - $m$, не само на глаголе V врсте: зват (звати, зовем), клат (клати, кољем), прат (прати, перем), слат (слати, шаљем) и др.

На крају, ваља констатовати да постоје и алтернације везане за основу а не за наставке: ма́стити, маิстӣм, маิшћен // маิштен; овла́стити, о̀вла̄стӣм, о̀вла̄шћен // о̀вла̄штен; опу́стити, о̀пӯстйм, о̀пӯшћен // о̀пуштен и сл. Ради се о морфолошкој категорији у којој је вршено старо прасловенско јотовање по којем су се зд, cm мењали се у жд, шт, али су се касније напоредо са њима или уместо њих почеле употребљавати групе жћ, $ш ћ$ које су резултат новог, штокавског јотовања и које су се овде рашириле аналогијом (в. Стевановић 1970: 138). И да напоменемо да сви дублетни облици трпног глаголског придева потврђују нашу тврдњу да се он никад не гради од презентске него увек и само од инфинитивне основе.

\section{РАДНИ ГЛАГОЛСКИ ПРИДЕВ И ГЛАГОЛСКИ ПРИЛОГ ПРОШЛИ}

Преостала два глаголска облика узимамо заједно јер им и дублетни облици имају исто објашњење. У то ћемо се лако уверити ако упоредимо дате примере, ако упоредимо, на пример, од глагола вйгнути, вйгнеем облике радног глаголског придева вйгнуо, -ула // вйгао, вйгла са облицима глаголског пилога прошлог вйгнуувши // вйга̄вши и др.:

А. вр̈гнути, вр̈гне̄м, вр̈гнуо, -ула // вр̈гао, вёгла, дйгнути, -не̄м, дйгнуо, -ула, -уло // дйгао, -гла, -гло, изма̀кнути, ѝзмакне̄м, изма̀кнуо // иेзмакао, изма̀кла и ѝзмакла, иста̀кнути, йстакне̄м, иста̀кнуо, -ула // ѝстакао, иста̀кла и йстакла, кйснути, -не̄м, кйснуо, -ла, -ло // кйсао, -сла, -сло, ма̀кнути / ма̀ћи, мӓкне̄м, ма̀кнуо, -ула // мӓкао, ма̀кла, мàкло, мёзнути, мёзнеем, мёзнуо, мйзнула // мёзао, мёзла, -ло, на̀викнути и на̀вићи,-не̄м, на̀викнуо, -ула, -уло // на̀викао, -кла, -кло, на̀гнути, нӓгне̄м, на̀гнуо, -ула, -уло // нӓгао, на̀гла, на̀гло, на̀пукнути и на̀пући, -укне̄м, на̀пукнуо, -ула, -уло // на̀пукао, -кла, -кло, ната̀кнути, ната̀ћи и на̀таћи, на̀такне̄м, ната̀кнуо, -ла, -ло // на̀такао, ната̀кла и на̀такла, нйкнути и нйћи, нйкне̄м, нйкнуо, -ула, -уло // нйкао, -кла, -кло, оेбикнути (се) и оेбићи (се), оेбикнемм (се), оेбкнуо, -ула, -уло // оेбикао, -кла, -кло, ода̀хнути, о̀дахне̄м, ода̀хнуо, -ула, -уло // оेдахао, ода̀хла и оेдахла, -ло, о̀мркнути и о̀мрћи, о̀мркне̄м, оेмркнуо, -ула, -уло // оेмркао, -кла, -кло, оेтврднути, -не̄м, оттврднуо, -ула, -уло // о̀тврдао, -дла, -дло, оте́гнути, оेте̄гне̄м, оте́гнуо, -ула, -уло // оттёгао, оте́гла и оेтёгла, -ло, оेтргнути, -не̄м, оттргнуо, -ула, -уло и оттргао, -гла, -гло, оेчврснути, -не̄м, оेчврснуо, -ла, -ло, оेчрсао, -сла, -сло, посегнути, посегнем, посегнуо, -ула, -уло // посегао, посегла и посегла, постигнути и постићи, постигнем, постигнуо, -ула, -уло // постигао, -гла, -гло, поте́гнути, поте́ћи и потећи, потегнем, потегнуо, -ула, -уло // потегао, потегла и потегла, по̀тиснути, -нём, по̀тиснуо, -ула, -уло // по̀тискао, -сла, -сло, про̀мрзнути, -не̄м, про̀мрзнуо, -ула // про̀мрзао, -зла, -ло, ра̀стргнути, -не̄м, ра̀стргнуо, -ула // ра̀стргао, -гла, -ло, са̀гнути, сӓгне̄м, са̀zнуо, -ула // cäzaо, сàzла, -ло, свр̈гнути, свр̈гне̄м, свр̈гнуо, -ула // свр̈гао, -гла, -ло, смр̈кнути, -не̄м, смйкнуо, -ула // смӥкао, -кла, -ло, спӱзнути (се), -не̄м (се), спӱзнуо, -ула // спӱзао, -зла, -ло, стйгнути и стӥћи, стйгне̄м, стӥгнуо, -ула // стйгао, -гла, -ло, та̀кнути и та̀ћи, тӓкне̄м та̀кнуо, -ула, -уло // тӓкао, та̀кла, -ло, у̀грезнути, -не̄м, у̀грезнуо, -ула // уेгрезао, -зла, -ло, у̀здигнути и уेздићи, -не̄м, у̀здигнуо, -ула // у̀здигао, -гла, -ло, у̀стукнути, -нём, уेстукнуо, -ла // уेстукао, -кла, -ло, у̀та̀кнути, ута̀ћи и у̀таћи, у̀такне̄м, ута̀кнуо, -ула // уेтакао, ута̀кла и у̀такла, ло, 
уте́гнути, у̀те́гне̄м, уте́гнуо, -ула // у̀те̄гао, уте́гла и у̀те̄гла, -ло, у̀тиснути, -не̄м, у̀тиснуо, -ула // уттискао, -сла, -ло, црекнути, црекне̄м, цйкнуо // цйкао, цйкла., и др.

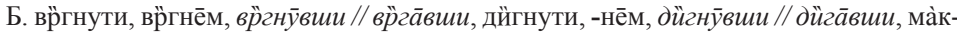

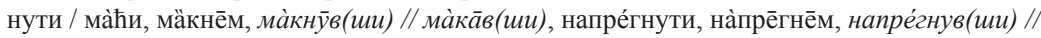
напре́zа̄в(uи), нате́гнути, на̀те̄гне̄м, нате́гнӯв(uи) // нате́zа̄в(uu), нйкнути и нйћи, нӥкне̄м,

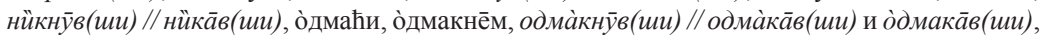

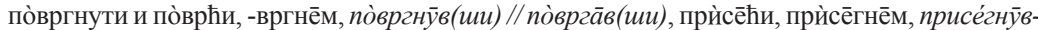

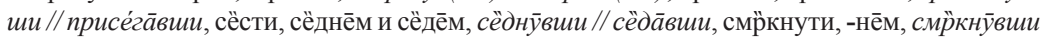
// смйка̄вщи, стйгнути и стӥћи, стйгне̄м, стйгнӯвщи // стйга̄вщи, у̀здигнути и у̀здићи,

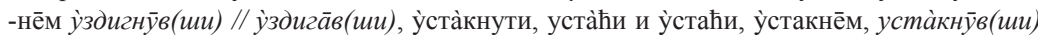

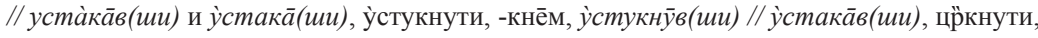

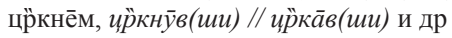

И овде као и код аориста типа такнух // такох имамо свршене глаголе. То, наравно, не значи да се ови облици граде само од свршених глагола. Граде се од глагола оба вида - како дигнуо, дигнувщи (// дигао, дигавщи) тако и чезнуо, чезнувши; тонуо, тонувши и сл.. То само значи да се дублети граде од свршених глагола, од оних глагола који испред -ну имају сугласник.. Некад су то, видели смо, били коренски глаголи и тад су начињени облици типа дигох, дигао, дигавши - и они су старији - а касније су преко наставака -ну- / -непрешли у тематске основе (које се завршавају на вокал) и од њих начинили одговарајуће облике дигнух, дигнуо, дигнувши. У нашем језику задржани су у употреби и једни и други. Опширније и детаљније о таквим дублетима видели смо код аориста - да се не понављамо.

\section{ЛИТЕРАТУРА}

Белић 1999: Александар Белић, Историја српског језика (Изабрана дела Александра Белића, т. 4), Београд: Завод за уџбенике и наставна средства.

Бошковић 2000: Радосав Бошковић, Основи упоредне граматике словенских језика, Београд: Требник.

Ђорђић 1975: Петар Ђорђић, Старословенски језик, Нови Сад: Матица српска.

Маретић 1963: Tomo Maretić, Gramatika hrvatskoga ili srpskoga književnog jezika, Zagreb: Matica hrvatska.

Меје 1951: А. Мейе, Общеславянский язык, Москва: Издательство иностранной литературы

Николић 2002: Светозар Николић, Старословенски језик I, Београд: Требник.

Симић 2001: Радоје Симић, Српска граматика I, Увод, фонологија, морфологија, Београд: МХ Актуел. 
Стакић 2010: Милан Стакић, Морфо(но)лошке теме, Београд: Друштво за српски језик и књижевност Србије.

Стакић 2011: Милан Стакић, О такозваним неправилним глаголима, Београд: Научни састанак слависта у Вукове дане 40/3, стр. 15-36.

Стакић 2012: Милан Стакић, Структура и развитак имперфекта у српском језику, Београд: Научни састанак слависта у Вукове дане 41/3, стр. 23-61.

Стакић 2013: Милан Стакић, Грађење имперфекта у савременом српском језику, Српски језик XVIII, Београд: Научно друштво за неговање и проучавање српског језика, 87-109.

Стакић 2014: Милан Стакић, Морфолошка структура трпног глаголског придева у српском језику, Српски језик XIX, Београд: Научно друштво за неговање и проучавање српског језика, 147-166.

Стакић 2015: Милан Стакић, Дублетни глаголски облищи од презентске основе, Београд: Научни састанак слависта у Вукове дане 44/3, стр. 7-22.

Стевановић 1970: Михаило Стевановић, Савремени српскохрватски језик I, Београд: Научна књига.

\section{МОРФОЛОГИЧЕСКИЕ ДУБЛЕТЫ ГЛАГОЛЬНЫХ ФОРМ, ОБРАЗУЕМЫХ ОТ ИНФИНИТИВНОЙ ОСНОВЫ}

\section{Резюме}

Все глагольные формы, образуемые от инфинитивной основы (как, впрочем, и образуемые от презентной основы), характеризуют дублеты, различные формы однлгл и того же глагола: инфинитив - никнути // нићи, аорист - дигнух // дигох, имперфект - пецијах // печах, страдательное причастие - зван // зват, действительное причастие - макнуо // макао, деепричастие совершенного вида - седнувши // седавши. Дублеты этого типа различного происхождения: разные алломорфы основы, разные окончания при одинаковой основе, фонетические изменения на стыке основы и окончания, аналогичесие выравнения и т.п. Автор эти и подобные им явления толкует, обосновывая свои толкования анализом собранного материала из современного сербского языка.

Ключевые слова: глагольные формы, дублеты, инфинитивная основа, инфинитив, аорист, имперфект, причастия, деепричастие совершенного вида, чередования согласных, аналогия. 